\title{
Unilateral Submandibular Gland Aplasia Associated with Ipsilateral Parotid Gland Atrophy
}

\author{
Dong Hoon Kang, Dongbin Ahn, Jae Hyug Kim and Jin Ho Sohn \\ Department of Otolaryngology-Head and Neck Surgery, School of Medicine, Kyungpook National University, Daegu, Korea
}

\section{동측 이하선의 진행성 위축을 동반한 일측 악하선 결손 1 예}

강동훈 · 안동빈 · 김재혁 · 손진호

경북대학교 의과대학 이비인후-두경부외과학교실

\author{
Received November 3, 2012 \\ Revised December 11, 2012 \\ Accepted December 14, 2012 \\ Address for correspondence \\ Dongbin Ahn, MD \\ Department of Otolaryngology- \\ Head and Neck Surgery, \\ School of Medicine, \\ Kyungpook National University, \\ 130 Dongdeok-ro, Jung-gu, \\ Daegu 700-721, Korea \\ Tel $+82-53-420-5777$ \\ Fax $+82-53-423-4524$ \\ E-mail entgodlikeu@gmail.com
}

The isolated unilateral aplasia of the submandibular gland (SMG) is an extremely rare condition, because most cases of congenital absence of the major salivary glands are associated with other anomalies and several major salivary glands. Worldwide, only 15 cases of isolated unilateral SMG aplasia have been reported. Here, we report a case of a 35-year-old woman with isolated unilateral SMG absence. The ipsilateral parotid gland was hypertrophied at the time of initial diagnosis, but this gland showed significant atrophy during the subsequent 3-year followup. This phenomenon may be associated with ipsilateral SMG aplasia, and we report this unique case along with a literature review in this paper.

Korean J Otorhinolaryngol-Head Neck Surg 2013;56:365-8

Key Words Abnormalities · Atrophy $\cdot$ Parotid gland $\cdot$ Submandibular gland.

\section{서 론}

선천성 타액선의 무형성증은 1885 년 Gruber에 의해 양측 악하선 결손이 처음 기술된 이래, 전 세계적으로 2011년까지 35예 정도만이 보고되고 있는 매우 드문 선천성 기형으로 양 측의 주타액선이 모두 없는 경우가 가장 흔한 형태로 알려져 있다. ${ }^{1-3)}$ 다발성의 타액선 무형성증의 경우 태생기 때 외배엽의 기형이나 눈물기관의 기형, Treacher-Collins syndrome과 같 은 안면기형, 측두하악골 부분의 기형 등이 함께 발견되는 경 우가 많으나, 단일 주타액선 무형성증은 동반 기형 없이 발생 하기도 하는데, 이 중 일측성 악하선 무형성증의 경우 현재까 지 전 세계적으로 불과 15 예 정도만이 보고되고 있는 극히 드 문 발생이상이다.5) 본 저자들은 이하선의 반복적인 종창을 주 소로 내원한 35세 여자 환자에게서 우연히 발견된 일측 악하 선의 결손 및 동측 이하선의 진행성 위축을 경험하였기에 이 를 문헌고찰과 함께 보고하는 바이다.

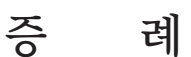

평소 건강하던 35세 여자 환자가 2주 전부터 간헐적으로 발 생하는 우측 이하선의 종창과 압통을 주소로 내원하였다. 증 상은 주로 식사 중이나 식사 후에 발생하였으나, 시간이 흐르면 저절로 호전되는 양상을 보였으며, 전신적인 열감이나 오한 등 의 동반증상은 없었다. 환자는 4년 전 치아우식증으로 발치한 병력이 1 회 있었으나 전반적인 구강 위생은 양호하였으며, 내 원 당시 추가적인 치아 우식증이 있거나 주관적인 구강 건조감 등의 증상은 전혀 호소하지 않았다. 병력청취 및 기본 혈액검 사, 기타 신체 검진은 모두 정상 소견이었으며, 과거력 및 가족 력에 있어서도 특이 사항은 없었다.

경부 초음파 검사에서 우측 이하선이 좌측에 비해 비대해져 있는 양상과 더불어 이하선내 림프절 종대가 확인되어 세침흡 입검사를 시행하였으며, 그 결과 반응성 림프절 과증식증을 보인 것 이외에는 특이소견이 없었다. 좌측 악하선의 경우 약간 
비대해져 있기는 했으나 특별한 종물이나 염증, 타석 등의 소 견은 보이지 않았으며, 우측 악하선이 명확히 관찰되지 않아 경부 전산화단층촬영을 추가로 시행하였다. 경부 전산화단층 촬영에서 우측 악하선의 대부분이 지방 세포로 치환되어 악 하선 실질은 관찰되지 않았으며(Fig. 1A), 또한 좌측 이하선 에 비해 우측 이하선이 상당히 비대되어 있는 양상을 보였다 (Fig. 1B). 이러한 우측 이하선의 비대는 동측 악하선 결손에 따른 보상적 작용에 의한 것으로 생각되었으며, 이하선 마사 지 등의 대증적 치료 이후 환자의 우측 이하선 비대는 점차 호전되는 양상을 보였다.

이로부터 3 년 후, 환자는 구강 건조감 및 간헐적인 양측 이 하선 주위의 부종을 다시 호소하였으며, 타석증 및 종양성 병 변의 감별을 위해 경부 전산화단층촬영을 한번 더 시행하였 다. 전산화단층촬영에서 우측 악하선 결손은 이전과 변함없 이 관찰되었으나(Fig. 2A), 우측 이하선의 경우 좌측 이하선에 비하여 현저하게 작은 것을 발견하였고 3 년 전 시행한 전산화
단층촬영에서의 이하선 크기와 비교했을 때도 심하게 위축 되어 있음을 확인할 수 있었다(Fig. 2B). 이후 타액선의 기능 평가를 위한 Tc-99m pertechnetate 스캔에서도 우측 악하 선의 기능적 결손을 확인할 수 있었으며, 우측 이하선 또한 위 축으로 인한 중증의 흡수 감소를 나타내었다(Fig. 3). 구강 건 조감 및 진행성 이하선 위축과 관련하여 쇼그렌 증후군을 감 별하기 위해 류마티스 내과와 협진을 시행한 결과, 자가항체 (anti-SSA/Ro, anti-SSB/La, antinuclear antibody, rheumatoid factor) 검사에서는 모두 음성이었고, 부타액선의 조직검 사에서도 경미한 만성타액선염 이외에 쇼그렌 증후군에 준 하는 병리 소견은 전혀 확인할 수 없었다.

결국 상기 환자는 우측 악하선 결손과 이에 수반된 동측 이 하선의 만성 타액선염 및 이로 인해 진행성 이하선 위축이 발 생한 것으로 생각되었으며, 현재는 구강 건조증상에 대해 타액 분비 촉진제를 사용하면서 특별한 불편감 없이 생활하고 있다.
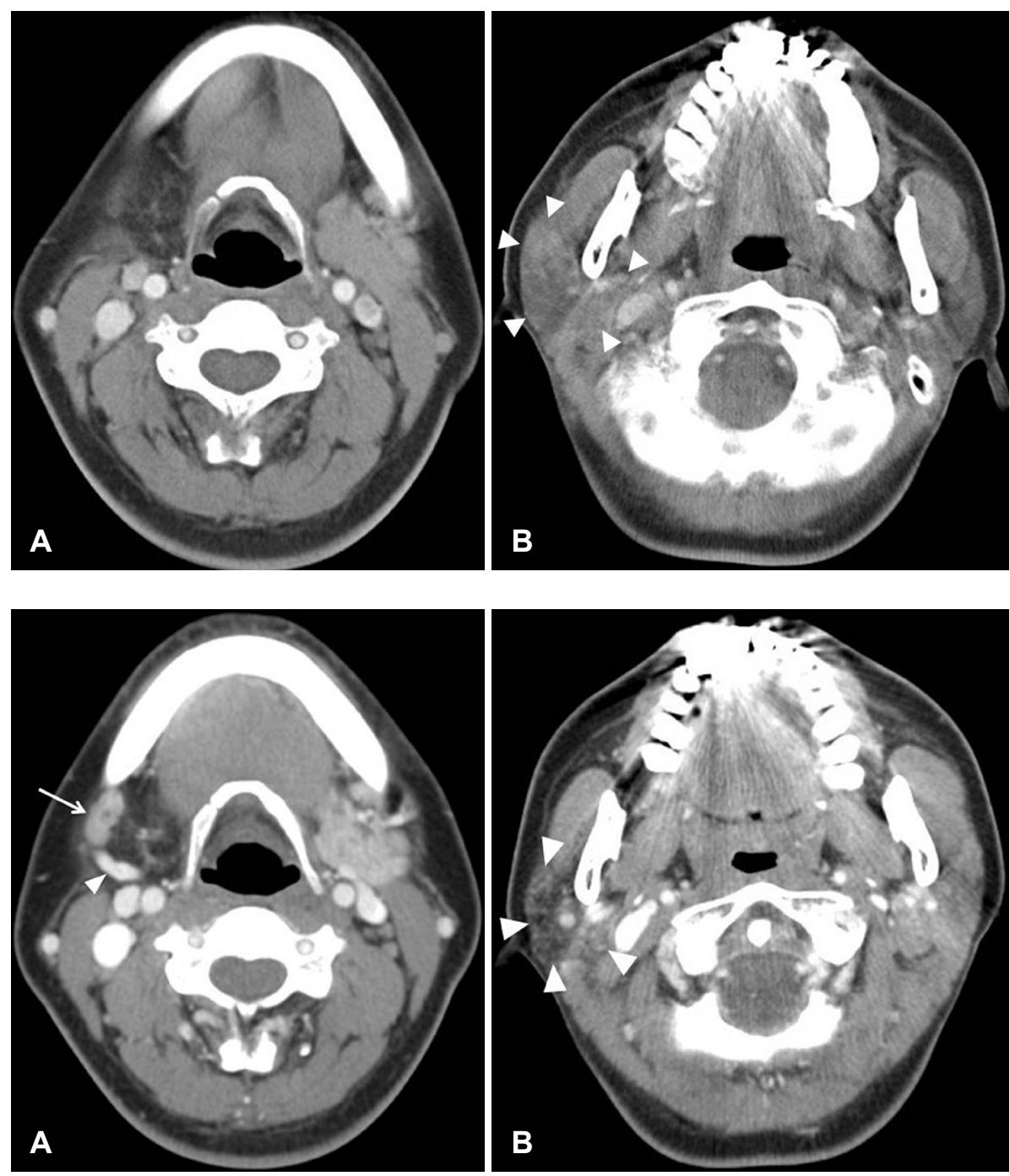

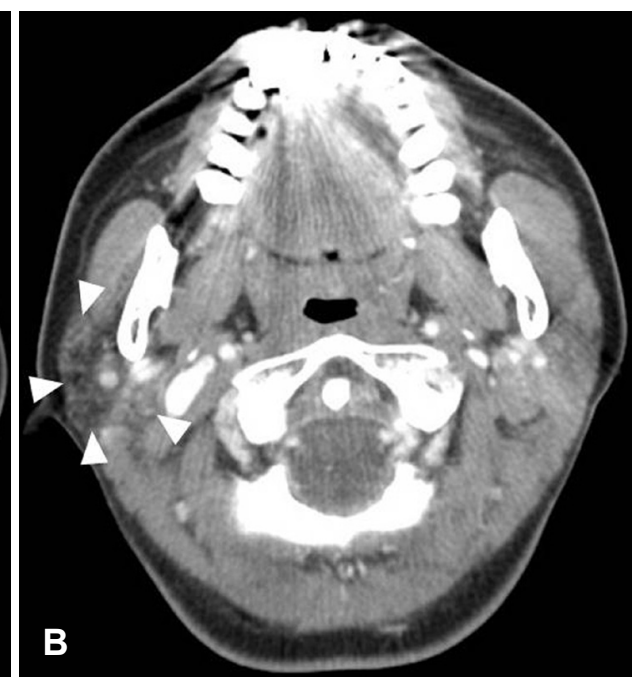

Fig. 1. Axial neck CT scan shows absence of the right submandibular gland with complete replacement by fat tissue (A). Right parotid gland (arrow head) shows a hypertrophied appearance in comparison with the left parotid gland (B).
Fig. 2. Axial neck CT scan obtained 3 years after the absence of the right submandibular gland was detected. Lymph node (arrow) and facial artery (arrow head) are seen in the right submandibular triangle, but the submandibular gland cannot be identified (A). Right parotid gland (arrow head) exhibits inflammatory changes and is significantly more atrophied than it was 3 years back (B). 


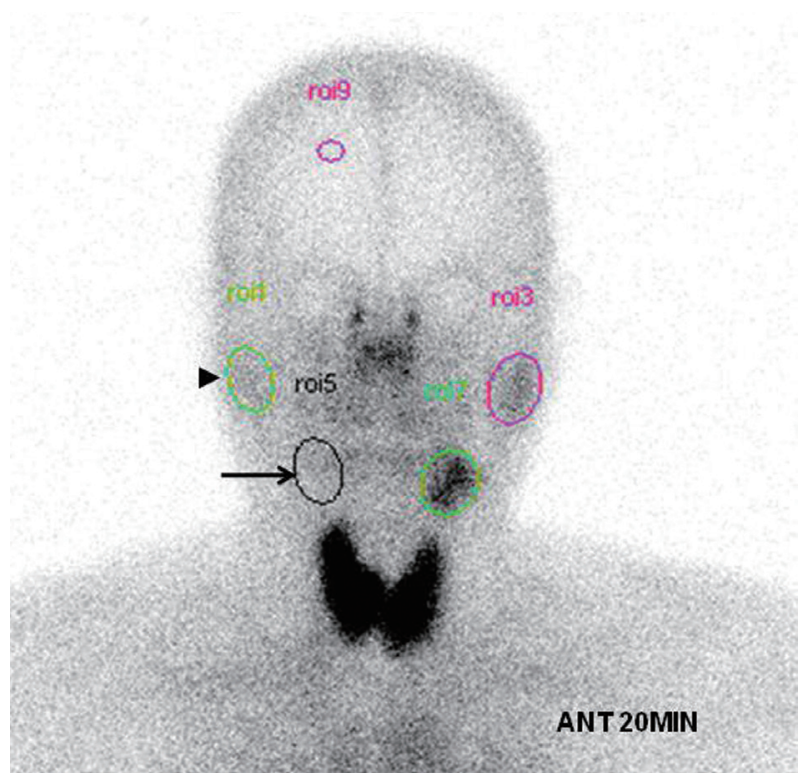

Fig. 3. Tc-99m pertechnetate scintiscan shows severely decreased uptake in the right parotid gland (arrow head) and absence of the right submandibular gland (arrow).

\section{고 찰}

발생학적으로 가장 먼저 형성되는 타액선은 이하선으로, 태 생 6주 초에 외배엽 상피에서 발생하기 시작한다. 이후 악하선 이 태생 6주 말에서 7주경 내배엽 상피아에서 발생하기 시작하 여 16 주 경에는 본격적인 분비 활동을 시작하며, 마지막으로 설하선이 태생 8주경에 내배엽 상피아에서 발생하게 된다. 이 러한 발생과정과 연관된 선천적인 타액선 결손을 타액선의 무형성(aplasia) 혹은 무발생(agenesis)이라고 하며, ${ }^{6}$ 현재까 지 전세계적으로 35 예 정도가 보고되어 있으나 그 원인은 아직 까지도 명확히 밝혀지지는 않았다. ${ }^{1)}$ 이 중 일측성 악하선 무형 성증에 대한 보고는 극히 드물어서 저자들이 대한이비인후과 학회지, 한국의학논문데이터베이스, 그리고 pubmed 등을 통 해 검색해 본 결과, 2012년 현재까지 전세계적으로 약 15예 정 도의 해당 보고를 확인할 수 있었으며,5) 국내에서도 2006년 에 일측성 악하선 무형성증 증례가 처음으로 보고된 이래, 현 재까지 단 2예만이 보고되어 있었다.,8) 하지만 타액선 결손이 단발성으로 발생한 경우 대부분 특별한 증상이 없고, 이 때문 에 주로 다른 증상에 대한 검사를 시행하는 과정에서 우연히 발견된다는 점을 고려할 때 실제 빈도는 이보다 횔씬 높을 것 으로 추정되며, 향후 건강에 대한 관심이 많아지고 영상검사 의 기술이 발전함에 따라 그 발견 빈도는 점차 증가할 것으로 생각된다.

일측성 악하선 무형성증의 증상은 건측 침샘의 보상작용 정도에 따라 발현양상을 달리하는데, 대개 타액분비 감소에
의한 구강 건조감이 흔히 나타나게 되고, 저작이나 연하곤란 의 형태로 나타나기도 한다. ${ }^{2.5,7)}$ 이러한 경우 치료는 대부분 해 당 증상에 따른 보존적 치료로써 pilocarpine hydrochloride 같은 타액분비촉진제를 사용하며 구강 청결 및 불소를 이용 하여 치아 우식증을 예방하고 구강 감염이 있을 경우에는 적 절한 항생제를 사용하는 것이다. 하지만 국내외에서 발표된 10 여개의 문헌들을 고찰해 보았을 때, 타액선 무형성증과 직 접적으로 관련된 증상을 나타낸 경우는 각각 구강 건조와 연 하곤란을 호소했던 2예만이 있었다. ${ }^{910)}$ 본 예에서도 우측 악 하선 무형성증은 우측 이하선 종창의 원인을 진단하는 과정에 서 우연히 발견되었다고 할 수 있겠으나, 상기 환자에서의 우 측 이하선 종창은 동측의 악하선 무형성증에 의한 보상반응 이었을 수 있으므로, 이는 악하선 결손으로 인해 발생한 이차 적 증상으로 볼 수도 있다.

현재까지 보고된 선천성 타액선 무형성증 증례들을 살펴보 면 대부분에서 반대측 주타액선의 보상적 비대를 확인할 수 있었다고 하였으며, ${ }^{11)}$ Yilmaz 등기 및 Herrera-Calvo 등ㄱㅇㅢ 보 고에서는 일측 악하선 무형성증 환자에서 전산화단층촬영과 자기공명영상 등을 이용하여 동측 설하선의 비대를 확인하 기도 하였다. 본 증례에서도 처음 일측 악하선 무형성 진단 당 시 동반된 동측 이하선의 보상적 비대가 확인되어 기존의 증 례들과 부합하는 소견을 보였으나, 3여년의 기간 동안 해당 이 하선의 위축이 발생했다는 점은 매우 특이할만 하였다. 이와 관련하여 쇼그렌 증후군과 같은 자가면역성 타액선염에 의 해 발생한 이하선 위축의 가능성을 고려하였으나, 혈청학적 그리고 병리학적 검사에서 이에 부합하는 소견은 확인할 수 없었으며, 임상적으로도 자가면역성 타액선염의 경우에는 양 측 이하선을 주로 침범한다는 점을 고려할 때, ${ }^{12)}$ 본 환자에서 발생한 일측성 이하선 위축은 동측 악하선의 결손으로 인해 발생한 이하선의 보상적 비대가 수년여의 기간에 걸쳐 반복적 이고 지속적인 염증을 초래한 결과로 사료된다. 실제로 타액선 관의 결찰이나 타석증에 의해 발생한 만성 타액선염에서의 연구를 살펴보면 초기에는 관세포 주위의 림프구 침윤과 관 의 불규칙한 확장이 발생하며, 이어서 선방세포의 위축 및 실질의 지속적인 섬유화 과정을 거치면서 궁극적으로는 타액 선의 소실에 이르게 되는 것으로 알려져 있다. ${ }^{13)}$

본 증례에서는 초음파 및 두 차례에 걸친 경부 전산화단층 촬영, 그리고 타액선 스캔 등의 검사를 통해 우측 악하선의 무 형성을 확진할 수 있었으며, 이에 수반된 동측 이하선의 보상 적 비대에서 위축에 이르는 과정을 객관적으로 확인할 수 있 었다. 이러한 현상은 일측 악하선의 결손으로 인한 하나의 연 쇄반응으로 생각되며, 단독으로 발생한 주타액선의 선천적 결손이 추가적인 주타액선의 후천적 위축으로 이어질 수 있음 
을 시사하는 증례로 생각된다. 따라서 무증상의 일측성 주타 액선 결손 환자에서도 장기적인 추적관찰을 통해 남아 있는 주타액선들의 기능을 정기적으로 평가하는 것이 필요할 것으 로 판단되며, 영상학적 검사의 발달과 더불어 향후 늘어날 것 으로 짐작되는 이러한 타액선 무형성증에 대한 자료를 축적 함으로써 그 병태생리 및 임상적 의의에 대한 보다 많은 이해 가 이루어 질 수 있을 것으로 생각된다. 이에 본 저자들은 동 측 이하선의 진행성 위축을 동반한 일측 악하선 결손 1 예를 문헌고찰과 함께 보고하는 바이다.

\section{REFERENCES}

1) Yan Z, Ding N, Liu X, Hua H. Congenital agenesis of all major salivary glands and absence of unilateral lacrimal puncta: a case report and review of the literature. Acta Otolaryngol 2012;132(6):671-5.

2) Kubo $S$, Abe K, Ureshino T, Oka M. Aplasia of the submandibular gland. A case report. J Craniomaxillofac Surg 1990;18(3):119-21.

3) Smith NJ, Smith PB. Congenital absence of major salivary glands. Br Dent J 1977;142(8):259-60.

4) McDonald FG, Mantas J, McEwen CG, Ferguson MM. Salivary gland aplasia: an ectodermal disorder? J Oral Pathol 1986;15(2):115-7.

5) Herrera-Calvo G, García-Montesinos-Perea B, Saiz-Bustillo R, GalloTerán J, Lastra-García-Barón P. Unilateral submandibular gland aplasia with ipsilateral sublingual gland hypertrophy presenting as a neck mass. Med Oral Patol Oral Cir Bucal 2011;16(4):e537-40.

6) Jeong HS, Koo GJ, Kim YC, Koo SK. Unilateral parotid glandular aplasia and ductal atresia. Korean J Otolaryngol-Head Neck Surg 1999;42(3):377-9.

7) Byun NC, Seo MH, Cho JH, Kim KT. A case of unilateral submandibular glandular aplasia. Korean J Otolaryngol-Head Neck Surg 2006;49(9):956-8.

8) Aiyappan SK, Ranga U, Veeraiyan S. Isolated unilateral aplasia of submandibular gland: a rare anomaly detected incidentally on computerized tomography. Oral Surg Oral Med Oral Pathol Oral Radiol Endod 2010;110(2):e54-6.

9) Yilmaz M, Karaman E, Isildak H, Enver O, Kilic F. Symptomatic unilateral submandibular gland aplasia associated with ipsilateral sublingual gland hypertrophy. Dysphagia 2010;25(1):70-2.

10) Gallego L, Junquera L, Cuesta P, Rosado P. Symptomatic unilateral submandibular gland aplasia. Br J Oral Maxillofac Surg 2009;47(3): 243.

11) Ahn D, Chun BS, Sohn JH, Park J. A case of unilateral absence of the submandibular gland secondary to sialolithiasis. Korean J Otorhinolaryngol-Head Neck Surg 2011;54(2):154-7.

12) Kassan SS, Moutsopoulos HM. Clinical manifestations and early diagnosis of Sjögren syndrome. Arch Intern Med 2004;164(12): 1275-84.

13) Teymoortash A, Tiemann M, Schrader C, Werner JA. Characterization of lymphoid infiltrates in chronic obstructive sialadenitis associated with sialolithiasis. J Oral Pathol Med 2004;33(5):300-4. 